\title{
Floristic Diversity and Pastoral Value of Permanent Grassland Fertilized in Conventional and Organic System
}

\author{
Neculai DRAGOMIR ${ }^{1 *}$, Maria SAUER ${ }^{2}$, Ioan SAUER ${ }^{2}$, Marcela DRAGOȘ ${ }^{1}$, Dorin RECHIȚEAN ${ }^{1}$ \\ ${ }^{1}$ Lovrin Agricultural Research and Development Station, Principala St. no. 200, 307250 Lovrin, Timiș \\ County, Romania \\ ${ }^{2}$ Caransebeș Sheep Research and Development Station, Drumul Reșiței St. no. 2, 325400 Caransebeș, \\ Carș-Severin County, Romania \\ *corresponding author: dragomir_ne@yahoo.com
}

Bulletin UASVM series Agriculture 77(1) / 2020

Print ISSN 1843-5246; Electronic ISSN 1843-5386

DOI:10.15835/buasvmcn-agr: 2018.0040

\begin{abstract}
Permanent grassland is the most complex natural ecosystem due to the biodiversity of the structural and functional elements that characterize the space and time unit of this ecosystem. From this point of view, in the case of this ecosystem, biodiversity is manifested by the richness of species as a result of the interactions between species and the biotope, the interspecific relations and the effects of the technology and usage applied to the improvement of these surfaces. The paper presents the results obtained in an experimental device placed on a permanent grassland of Festuca valesiaca + Festuca rupicola, from Caraş-Severin County, under conditions of mineral and organic fertilizers application (sheep manure and direct fertilization by sheep folding).
\end{abstract}

Keywords: permanent pasture, production, botanical composition, biodiversity indices, pastoral value

\section{INTRODUCTION}

Permanent grassland is the most complex natural ecosystem due to the biodiversity of the structural and functional elements that characterize the space and time unit of this ecosystem. From this point of view, in the case of this ecosystem, biodiversity is manifested by the richness of species as a result of the interactions between species and the biotope, of the interspecific relations and the effects of the technology and usage applied to the improvement of these surfaces.

The total surface of permanent grasslands in the world is 3.40 billion hectares $(25.7 \%$ of the total land area and $69.3 \%$ of the agricultural area of the Earth). From this area Europe has an area of 184 million hectares (5.6\%), 7.7\% of the total area of a continent and $34.6 \%$ of the agricultural area (White, 1983, Smit et al. 2008). Total phytomass output of Terra's grasslands is estimated at 1000 million tons, which directly or indirectly provides much of the resources needed to the lives of over 800 million inhabitants.

The structure of permanent grassland areas per vegetation area is as follows: 0.63 million hectares (13\%) plain and plateau grassland, 1.44 million hectares (30\%) high hills and high plateaus grasslands; 2.16 million hectares (45\%) mountain grasslands; 0.10 million hectares $(2 \%)$ alpine grasslands; 0.48 million hectares (10\%) interzonal and zonal grasslands (river meadows, halophiles and psamophiles grasslands). The total area affected by natural limiting factors (erosion, slope, excess moisture, invasive species, etc.) is over 600 thousand hectares representing $10-15 \%$ of the area of each type of grassland, structured on vegetation areas (Dragomir et al., 2018 ). 
The paper presents the results obtained in an experimental device placed on a permanent grassland of Festuca valesiaca + Festuca rupicola, from Caraş-Severin County, under conditions of mineral and organic fertilizers application (sheep manure and direct fertilization by sheep folding).

\section{MATERIALS AND METHODS}

The research was carried out during 20152017 on a permanent grassland of Festuca valesiaca + Festuca rupicola in Caraş-Severin county, used exclusively with sheep.

The experimental device included four experimental variants, fertilized with mineral and organic fertilizers: V1 - unfertilized grassland (control), V2 - fertilization with complex mineral fertilizers (300 kg $+\mathrm{N}_{100}$ ), V3 - organic fertilization (sheep manure, $30 \mathrm{~T} / \mathrm{ha}$ ), V4 - fertilization by sheep folding + over-sowing $+\mathrm{P}_{100}$.

The variants were established in 2015: organic fertilizers, complex mineral fertilizers and phosphorus were applied only at establishment, and nitrogen fertilizers were applied during vegetation. In case of $\mathrm{V} 4$, after fertilization through sheep folding ( 1 sheep $/ \mathrm{m}^{2}$ ) for four nights, oversowing with a mixture of grasses and legumes was carried out (Lolium perenne $40 \%+$ Festuca pratensis 30\% + Festuca arundinacea 10\% + Lotus corniculatus $10 \%+$ Trifolium repens $10 \%$ )

During the 2015-2017 years, the following parameters were determined: phytomass production, grazing capacity (GC), floral composition, pastoral value (PV), the value of some biodiversity indices (Shannon-Weaver - H', Simpson - D, echitability - EH').

\section{RESULTS AND DISCUSSIONS}

Following conventional fertilization (by application of mineral fertilizers) of the studied permanent grassland, the production of phytomass increased from $7.29-7.83 \mathrm{t} / \mathrm{ha}$, on the unfertilized variant, to $15.65-18.36 \mathrm{t} / \mathrm{h}$. In the case of organic fertilization (sheep manure), green mass production increased to 13.37 - 15.48 t/ha. The variant fertilized through sheep folding and over-sowing recorded the highest production increase of 18.21 - $20.46 \mathrm{t} / \mathrm{ha}$. The increase of the phytomass production also led to an increase of the grazing capacity, from $0.61-0.66 \mathrm{UVM} / \mathrm{ha}$, on the unfertilized variant, to $1.34-1.57 \mathrm{UVM} / \mathrm{ha}$, on the mineral fertilized variant, to 1.14 - $1.32 \mathrm{UVM} /$ ha, on organically fertilized variant and to 1.59 $1.79 \mathrm{UVM} /$ ha on the variant fertilized through sheep folding and over-seeded (Tab. 1).

Permanent grassland are considered the most complex natural ecosystem due to the biodiversity of existing species. Thus, the richness of species, expressed by its number, varies greatly from one variant to another. As compared to the control variant, with a number of 56 species in 2016 and 51 species in 2017, the richness of species decreases to 28-37 species in the mineral fertilized variant and to 30-45 species in organic fertilized variant. In case of the variant fertilized through sheep

Table. 1. Influence of mineral and organic fertilization on production and grazing capacity (GC)

\begin{tabular}{|c|c|c|c|c|c|c|}
\hline \multirow{3}{*}{ Variant } & \multirow{2}{*}{\multicolumn{2}{|c|}{$\begin{array}{l}\text { Phytomass } \\
\text { production }\end{array}$}} & \multicolumn{4}{|c|}{ Grazing capacity } \\
\hline & & & \multicolumn{2}{|c|}{2016} & \multicolumn{2}{|c|}{2017} \\
\hline & 2016 & 2017 & Real GC ${ }^{1}$ & $\begin{array}{l}\text { Usable } \\
\text { GC }^{2}\end{array}$ & Real GC ${ }^{1}$ & $\begin{array}{l}\text { Usable } \\
\text { GC }^{2}\end{array}$ \\
\hline V1 - unfertilized & 7.83 & 7.29 & 0.82 & 0.66 & 0.76 & 0.61 \\
\hline $\begin{array}{l}\text { V2 - fertilization with chemical } \\
\text { fertilizers }\left(\mathrm{NPK}_{300}, \mathrm{~N}_{100}\right)\end{array}$ & 15.65 & 18.36 & 1.63 & 1.34 & 1.91 & 1.57 \\
\hline $\begin{array}{l}\text { V3 - organic fertilization (sheep } \\
\text { manure, } 30 \mathrm{~T} / \mathrm{ha} \text { ) }\end{array}$ & 13.37 & 15.48 & 1.39 & 1.14 & 1.61 & 1.32 \\
\hline $\begin{array}{l}\text { V4 - fertilization by sheep folding and } \\
\text { over-sowing }\left(\mathrm{P}_{100}\right)\end{array}$ & 18.21 & 20.46 & 1.89 & 1.59 & 2.13 & 1.79 \\
\hline
\end{tabular}


Table. 2. The influence of mineral and organic fertilization on the number of species, pastoral value (PV) and biodiversity indices (2016)

\begin{tabular}{lccccc}
\hline \multicolumn{1}{c}{ Variant } & No. of & & \multicolumn{2}{c}{ Biodiversity indices } \\
\cline { 5 - 7 } & species & PV & H' & D & EH' \\
\hline V1 - unfertilized & 56 & 34.4 & 4.6321 & 0.262 & 0.263 \\
\hline V2 - fertilization with chemical fertilizers $\left(\mathrm{NPK}_{300}, \mathrm{~N}_{100}\right)$ & 37 & 44.4 & 3.1673 & 0.346 & 0.355 \\
\hline V3 - organic fertilization (sheep manure, 30 T/ha) & 45 & 47.2 & 3.8606 & 0.408 & 0.412 \\
\hline V4 - fertilization by sheep folding and over-sowing $\left(\mathrm{P}_{100}\right)$ & 10 & 87.0 & 1.5848 & 0.921 & 0.874 \\
\hline
\end{tabular}

Table. 3. The influence of mineral and organic fertilization on the number of species, pastoral value (PV) and biodiversity indices (2017)

\begin{tabular}{lccccc}
\hline \multicolumn{1}{c}{ Variant } & \multirow{2}{*}{$\begin{array}{c}\text { No. of } \\
\text { species }\end{array}$} & $\mathbf{P V}$ & & \multicolumn{2}{c}{ Biodiversity indices } \\
\cline { 5 - 7 } & 51 & 31.4 & 4.3592 & 0.369 & 0.341 \\
\hline V1 - unfertilized & 28 & 48.0 & 2.9060 & 0.698 & 0.780 \\
\hline V2 - fertilization with chemical fertilizers $\left(\mathrm{NPK}_{300^{\prime}}, \mathrm{N}_{100}\right)$ & 30 & 49.6 & 3.0157 & 0.583 & 0.702 \\
\hline V3 - organic fertilization (sheep manure, 30 T/ha) & 12 & 71.4 & 1.6312 & 0.843 & 0.912 \\
\hline V4 - fertilization by sheep folding and over-sowing $\left(\mathrm{P}_{100}\right)$ & 12 & & EH' \\
\hline
\end{tabular}

folding and over-seeding, the floral structure is formed in proportion of over $50 \%$ of grasses and leguminous species introduced into the grassland by over-seeding. Depending on the fodder value of the species in the floristic composition, the pastoral value (VP) of the grassland was determined, which recorded higher values for all fertilized or overseeded variants compared to the control (Tab. 2\&3).

The analysis of the biodiversity indices has revealed the following characteristics of the floristic structure: V1 - high diversity of species with very uneven distribution, V2 - medium diversity with relatively uniform distribution, V3 high diversity with relatively uniform distribution, V4 - low diversity with very uniform distribution species (Tab. 2\&3).

These results are similar to other researches carried out under the same type of permanent grassland (Păcurar and Rotar, 2014; Marusca et al., 2010, 2016; Samfira et al., 2011).

\section{CONCLUSION}

Improvement of floristic degraded permanent grassland can be achieved by different methods of conventional fertilization (mineral fertilizers) or organic fertilization (manure), taking into account the natural and stationary conditions.

Considering the use of permanent meadows by direct grazing with sheep, it is advisable to improve them by applying the sheep folding and over-sowing method, which, in case of the experimental device used, has led to an increase in the production and quality of the feed.

\section{REFERENCES}

1. Dragomir N. (2005). Pajiști şi plante furajere. Tehnologii de cultivare, Ed. Eurobit, Timișoara.

2. Dragomir N, Horablaga M, Dragoș M, Rechițean D, Neciu F (2017). Study of the behaviour of perennial ryegrass (Lolium perenne L.) in mixtures of perennial grasses and legumes, used by mowing and grazing. Agronomy Series of Scientific Research/Lucrări Științifice Seria Agronomie. 60(1):113-116. 
3. Dragomir N, Blaj A, Marușca T, Mocanu V, Horablaga M, Rechițean D, Dragoș M, Tod M, Ene T (2018). Pajiștile de câmpie - Cauzele degradării vegetației și măsuri tehnologice de îmbunătățire, Ed. ArtPress, Timișoara.

4. Marușca T, Mocanu V, Cardașol V, Hermenean I, Blaj A, Oprea G, Tod M (2010). Ghid de producere ecologică a furajelor de pajiști montane. Ed. Universității Transilvania, Brașov.

5. Marușca T (2016). Praticultura pe înțelesul tuturor. Ed. Coprint, ISBN 978-973-0-23325-4.
6. Păcurar F, Rotar I (2014). Metode de studii și interpretare a vegetației pajiștilor, Ed. Risopint, Cluj-Napoca.

7. Samfira I, Sărățeanu V, Moisuc A (2011). Elemente metodologice applicate în cercetarea pajiștilor, Ed. Mirton, Timișoara.

8. Smit HJ, Metzger MJ, Ewert F (2008). Spațial distribution of grasslend productivity and land use in Europe. Agricultural system (98).

9. White (1983). The vegetation of Africa. Paris UNESCO. 